\title{
Infestation of Magulacra nigripennata Dognin (Lepidoptera: Cossidae) in a commercial cupuassu plantation in Nova Califórnia, Rondônia State, Brazil
}

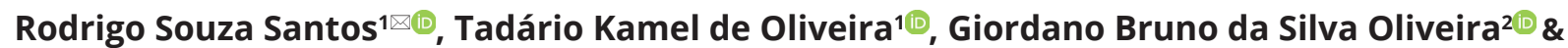 \\ Taysa Faltz Macedo3
}

1. Embrapa Acre, Brazil. 2. Universidade Federal do Acre (UFAC), Brazil. 3. Projeto RECA, Brazil.

\section{EntomoBrasilis 13: e912 (2020)}

Edited by:

William Costa Rodrigues

Article History:

Received: 22.vi.2020

Accepted: 21.ix.2020

Published: 06.x.2020

Corresponding author:

Rodrigo Souza Santos

乃 rodrigo.s.santos@embrapa.br

Funding agencies:

$\leftrightarrow$ Without funding declared

\begin{abstract}
The cupuassu (Theobroma grandiflorum (Willd ex Sprengel) K. Schum.) is a native tree from the tropical rainforest and one of the most important fruit trees in the Amazon region. Its pulp and seeds are widely used in the alimentary industry, as well as food by the people of northern Brazil. Among the factors that can compromise the production of cupuassu are the attack of diseases and insect pests. The aim of this work is to report the attack of a wood-borer lepidopteran in commercial cupuassu plantation located in the district of Nova Califórnia, Rondônia State, Brazil. In April 2019 an infestation of a wood-borer insect was observed causing the death of branches. Branches containing caterpillars in their inside were collected and taken to the Entomology Laboratory of the Embrapa Acre, where they were placed in a screened cage. After about 60 days, an adult insect emerged, which was identified as Magulacra nigripennata, a lepidopteran associated with cocoa and cupuassu plantations in that country. A random survey of 100 plants in the plantation area detected an infestation level of $36 \%$, indicating the harmful potential of this pest to the cupuassu crops in the Amazon region.
\end{abstract}

Keywords: Carpenter worm; Cossoidea; Magnoliopsida; Malvaceae; Western Amazon. $\square$ The genus Theobroma belongs to the Malvaceae family and currently encompasses 22 plant species, all of them distributed in the American continent (CUATRECASAS 1964; The Plant List 2013). Of these, the following thirteen species occur in the Brazilian Amazon: Theobroma bicolor Humb. and Bonpl.; Theobroma canumanense Pires and Fróes ex Cuatrec.; Theobroma obovatum Klotzsch ex Bernoulli; Theobroma subincanum Mart.; Theobroma microcarpum Mart.; Theobroma duckei Huber; Theobroma glaucum $\mathrm{H}$. Karst.; Theobroma simiarum Donn. Sm.; Theobroma velutinum Benoist; Theobroma speciosum Willd ex Sprengel; Theobroma sylvestre Aubl. ex Mart.; Theobroma cacao Linnaeus, and Theobroma grandiflorum (Willd. ex Sprengel) K. Schum. (Esteves 2015). The commercially cultivated species in Brazil are T. cacao (cocoa) and T. grandiflorum (cupuassu). In Brazil, T. grandiflorum is popularly known as "cupu", "pupu", "pupuassu", or "cupuassu" (Fraife Filho et al. 2009; Cavalcante 2010).

The cupuassu tree is native to the humid tropical rainforest of drylands and high floodplains, occupying the sub-canopy stratum of the forest. It can reach a height from 18 to $20 \mathrm{~m}$ in nature, and from 4 to $8 \mathrm{~m}$ when cultivated. It is a native plant of the Eastern Amazon, spread throughout the Amazon basin and northern Maranhão State, also reaching other Brazilian States (CAlzavara et al. 1984; Cavalcante 2010). The cupuassu is classified as an indehiscent fruit. It has 32 seeds on average, a rigid and woody epicarp, and green epidermis covered by a rusty and powdery indumentum (CARVALHO et al. 2004). The peel of the crushed fruit can be used as animal feed and/or organic fertilizer (CALZAVARA et al. 1984). Its pulp is widely used in the preparation of juices, marmalades, liquors, sweets, yogurts, ice creams, among others. The seeds are suitable for making chocolate ("cupulate") and extracting fat similar to cocoa butter (Venturieri \& Aguiar 1988).

Cupuassu crops in monocultures or as components of Brazil's Agroforestry Systems (AFS) are widely spread in the Brazilian Amazon (Gondim et al. 2001). Both forms of cultivation suffer due to the presence of associated insects, which may be harmful or not, depending on their population levels. The insects associated with cupuassu cultivation in Brazil are (1) coleopterans: Omophoita aequinoctialis (Linnaeus), Maecolaspis joliveti (Bechyné) (Coleoptera: Chrysomelidae), Demobarius sp., Heilipodus naevulus (Mannerheim), Carpophilus dimidiatus (Fabricius) and Conotrachelus humeropictus Fiedler (Coleoptera: Curculionidae), Xyleborus affinis Eichhoff and Hypocryphalus sp. (Coleoptera: Scolytidae), Steirastoma breve (Sulzer) (Coleoptera: Cerambycidae), Carpophilus dimidiatus (Fabricius) (Coleoptera: Nitidulidae); (2) hemipterans: Bocydium globulare (Fabricius) (Hemiptera: Membracidae), Hypselonotus sp. (Hemiptera: Coreidae), Monalonion annulipes Singnoret (Hemiptera: Miridae), Aphis (Toxoptera) citricida (Kirkaldy) (Hemiptera: Aphididae); (3) orthopterans: Eutropidacris cristata (Linnaeus) (Orthoptera: Acrididae); (4) lepidopterans: Macrosoma tipulata Hübner (Lepidoptera: Hedylidae) and Magulacra nigripennata Dognin (Lepidoptera: Cossidae) (PAmplona et al. 1992; TeIXeIRA \& Veld 1997; Gazel Filho \& Lima 2000; Jordão \& Silva 2006; Silva et al. 2007; Fraife Filho et al. 2009; Fraife Filho 2010; Silva et al. 2016; Jesus-Barros et al. 2016).

The aim of this work is to report the attack of a wood-borer lepidopteran in commercial cupuassu plantation located in the district of Nova Califórnia, Rondônia State, Brazil. 
In April 2019, a technical visit was made in a commercial plantation of cupuassu, in the property "Sítio Bom Jardim" (0945'43.8"S; 66³6'18.9"W) belonging to the RECA (Condensed Economic Reforestation Consortium) project.

Cupuassu trees were surveyed in two areas of the property. Area 1 had about 4.5 ha and 28 years old plants, whereas area 2 had about 2.7 ha and 27 years old plants. The average height of plants in both areas was 3 to $4 \mathrm{~m}$. The seedlings were planted with a spacing of $4 \times 7 \mathrm{~m}$ and, when necessary, periodic pruning against the attack of the "witche's broom disease", Moniliophthora perniciosa (Stahel) Aime and PhillipsMora (Tricholomataceae), was performed. However, no phytosanitary treatment against pests and diseases has been used since the establishment of the plantations.

To verify the level of infestation, a random inspection with the naked eye was performed on 100 plants (50 per area), counting those with perforated branches (Figure 1A), dry branches, and/or those with dead leaves. Branches with these characteristics were detached from the plants and cut longitudinally with a machete. The presence of galleries and red, white, and black colored caterpillars was verified in several branches (Figure 1B).

Three branches containing caterpillars were taken to the Entomology Laboratory of the Embrapa Acre (Brazilian Agricultural Research Corporation), municipality of Rio Branco, Acre State, Brazil, where they were packed in a roofed cage for insect breeding. The cage was inspected daily

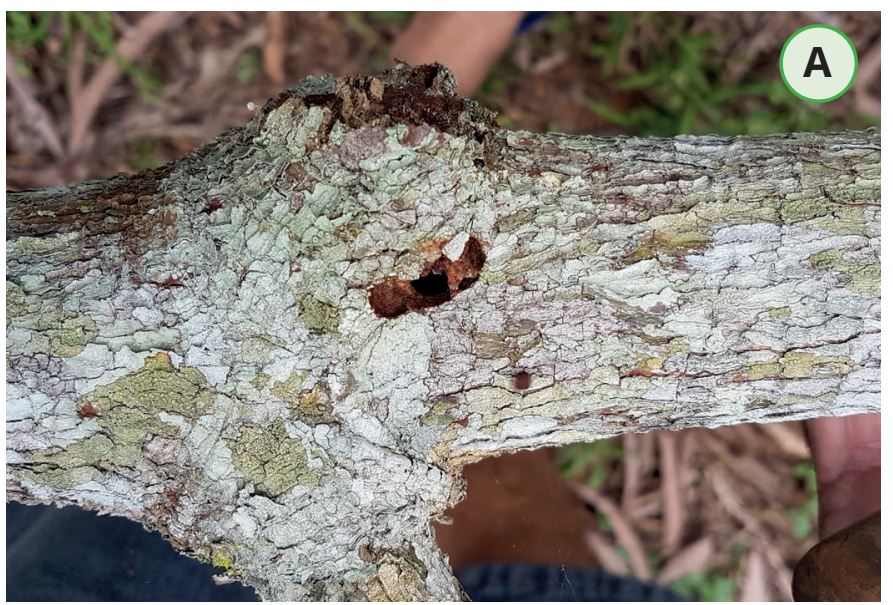

until the emergence of adult insects.

After about 60 days, an adult insect emerged, that was identified as M. nigripennata (Lepidoptera: Cossidae) (Figure 2), a species which had already been reported associated with cocoa and cupuassu by Trevisan et al. (2011) in the Rondônia State, Brazil. The insect was identified based on the studies by EID \& VIARD (1997) and Morgan (2013) and was deposited at the Entomological Collection of the Entomology Laboratory of the Embrapa Acre.

The family Cossidae belongs to the superfamily Cossoidea, which encompasses more than 670 described species globally distributed. These moths measure from 2.5 to 8.5 $\mathrm{cm}$ in wingspan and are popularly known as "goat moths", "leopard moths", or "carpenter worms". Adults are robust, with a large body, and a greyish coloration, and have nocturnal habits. The eggs are usually laid in slits or under the bark of their host plants (species of 17 families of angiosperms are currently known), requiring one to four years to complete their development (Rafael et al. 2012; Lotts \& Naberhaus 2017).

During their feeding, the caterpillars pierce and open galleries inside the branches and trunks of the plants, causing their ringing and hindering the passage of water, nutrients, and sap. Near the final stage of development, the caterpillars open a gallery across the branches and pupate close to the exit hole (Jesus-Barros et al. 2016). The attack of this insect leads to the drying out and death of the branches and, consequently, causes considerable damage to the

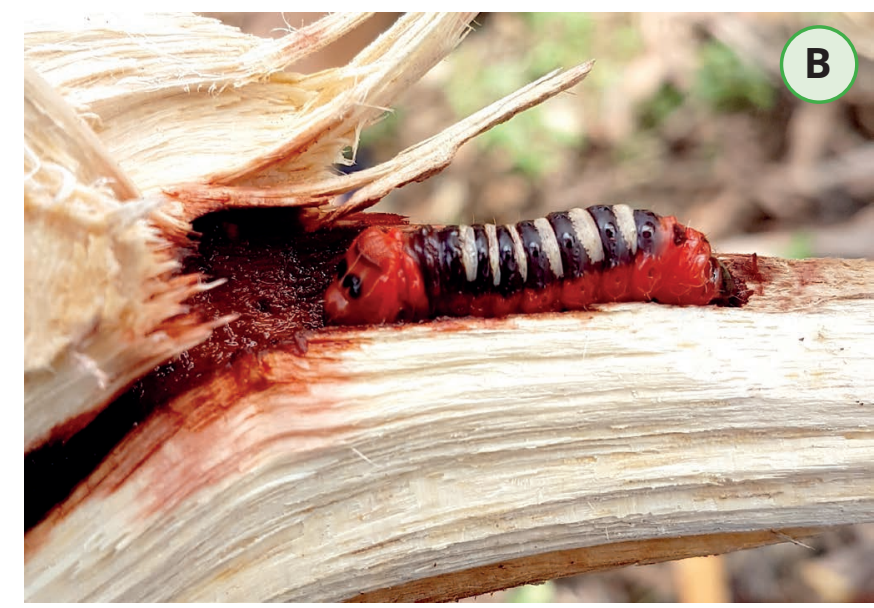

Figure 1. Entrance hole of Magulacra nigripennata Dognin (Lepidoptera: Cossidae) in a branch of Theobroma grandiflorum (A) and External morphological aspect M. nigripennata inside a cupuassu branch (B). (Pictures: Giordano Bruno da Silva Oliveira).

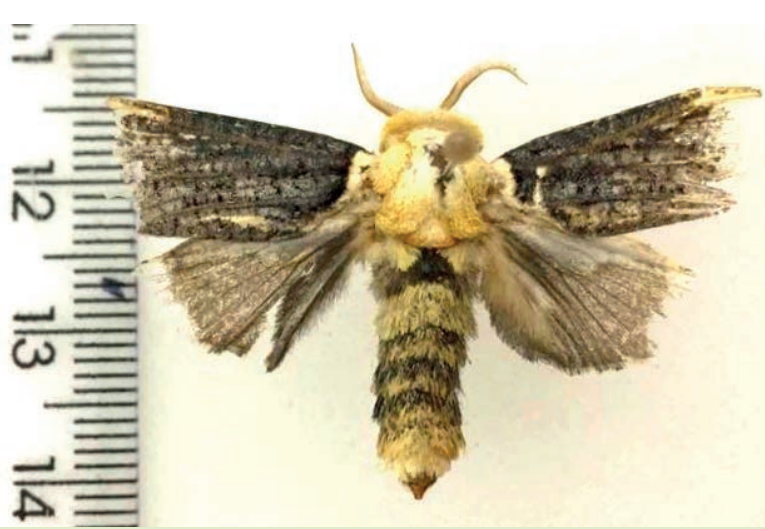

Figure 2. Magulacra nigripennata Dognin (Lepidoptera: Cossidae) adult in dorsal habitus. (Picture: Rodrigo Souza Santos).

production of cupuassu, although there is still no work that has quantified losses in production.

The occurrence records of $M$. nigripennata in the Brazilian Amazon are restricted to the States of Pará, Rondônia, and
Amapá (Mendes \& Garcia 1984; Jesus-Barros et al. 2016; Trevisan et al. 2016), although cupuassu cultivation is widespread throughout the region of the Brazilian Amazon. According to Silva \& PAMPLONA (2011), there are no studies on the biology, ecology, and control methods of this pest in the Amazon. 
Regarding control methods, so far, there are no products registered with the Brazilian Ministry of Agriculture, Livestock, and Food Supply (Mapa), and there are also no records of natural enemies associated with this species of insect pest in Brazil. TREVISAN et al. (2011) recommended monitoring the plantation on a monthly basis for symptoms of the presence of the pest and once detected, to perform the removal and burning of the infested branches. Spraying with insecticide based on Bacillus thuringiensis Berlinier is also indicated for wood-borer control (SILVA Neto et al. 2001).

In the survey carried out a level of infestation of $6 \%$ in area 1 and $30 \%$ in area 2 were found (36\% overall), demonstrating the broad infestation of this pest in this area. This level of infestation is an alert for producers to carry out systematic monitoring of their plantations.

Given the socio-economic significance of cocoa and cupuassu for the Amazonian population and the destructive potential of this insect for the production of these fruits, studies on prospecting for natural enemies, bioecology, and level of damage in addition to control methods are strongly recommended to mitigate the economic damage caused by the attack of $M$. nigripennata on plantations in this region.

\section{REFERENCES}

Calzavara, BBG, CH Muller \& ONC Kahwage, 1984. Fruticultura Tropical: o cupuaçuzeiro - cultivo, beneficiamento e utilização do fruto. Belém, Embrapa Amazônia Oriental.

Carvalho, JEU de, CH Muller, RM Alves \& RFR de Nazaré, 2004. Cupuaçuzeiro. Belém, Embrapa Amazônia Oriental (Comunicado Técnico, 115).

Cavalcante, P, 2010. Frutas comestíveis na Amazônia. $7^{a}$ ed. Belém, Museu Paraense Emílio Goeldi.

Cuatrecasas, J, 1964. Cacao and its allied, a taxonomic of the genus Theobroma. Contributions from the United States of the Natural Herbarium, 35: 379-614.

Eid, A \& M Viard, 1997. Butterflies and moths of the world. New Jersey, Chartwell Book.

Esteves, G, 2015. Theobroma. Available on: <http:// floradobrasil.jbrj.gov.br/jabot/floradobrasil/FB23617>. [Access in: 17.ix. 2020].

Fraife Filho, GA, 2010. Cultivo do cupuaçuzeiro para o estado da Bahia. Available on: <http://www.ceplac.gov.br/radar/ cupua\%C3\%A7uzeiro.htm> [Access in: 17.ix. 2020].

Fraife Filho, GA, WS Pinto \& JLL Dantas, 2009. Cupuaçu. pp. 171-184. In: Santos-Serejo, JA, JLL Dantas, CV Sampaio \& YS Coelho (Eds.). Fruticultura tropical: espécies regionais e exóticas. Brasília, Embrapa Informação Tecnológica.

Gazel Filho, AB \& JA de S Lima, 2000. Recomendações técnicas para o cultivo do cupuassuzeiro (Theobroma grandiflorum) no Amapá. Macapá: Embrapa Macapá (Comunicado Técnico, 12).

Gondim, TM de S, MJ Thomazini, M de JB Cavalcante \& JML Souza, 2001. Aspectos da produção de cupuaçu. Rio Branco: Embrapa Acre (Documentos, 67).

Jesus-Barros, CR de, AL Lima, R Adaime, NM Silva \& AMSR Pamplona, 2016. A broca-dos-ramos-do-cupuçuzeiro

\section{Suggestion citation:}

Santos, RS, TK de Oliveira, GBS Oliveira \& TF Macedo, 2020. Infestation of Magulacra nigripennata Dognin (Lepidoptera: Cossidae) in a commercial cupuassu plantation in Nova Califórnia, Rondônia State, Brazil. EntomoBrasilis, 13: e912.

Available in: doi: 10.12741/ebrasilis.v13.e912
(Magulacra nigripennata Dognin, 1924) no Amapá. Macapá: Embrapa Macapá (Comunicado Técnico, 141).

Jordão, AL \& RA da Silva, 2006. Guia de pragas agrícolas para o manejo integrado no Estado do Amapá. Ribeirão Preto: Editora Holos.

Lotts, K. \& T Naberhaus, 2017. Butterflies and moths of North America. Available on: <http://www.butterfliesandmoths. org/taxonomy/Cossidae>. [Access in: 17.ix. 2020].

Mendes, ACB \& JJS Garcia, 1984. Biology of the cacao beetle, Steirastoma breve (Coleoptera, Cerambycidae). Revista Theobroma, 14: 61-68.

Morgan, S, 2013. The illustrated world encyclopedia of butterflies and moths: a natural history and identification guide. London: Lorenz Books.

Pamplona, AMSR, A das GC Souza, CD Nunes, RR Guimarães \& LAC Moraes, 1992. Levantamento da entomofauna do cupuaçuzeiro Theobroma grandiflorum Schum. em áreas experimentais da Embrapa-CPAA e de produtores. Manaus: Embrapa Amazônia Ocidental (Circular Técnica, 15).

Rafael, JA, GAR Melo, CJB de Carvalho, SA Casari \& R Constantino, 2012. Insetos do Brasil: diversidade e taxonomia. Ribeirão Preto: Holos.

Silva, NM da \&AMSR Pamplona, 2011. Impacto da entomofauna nos cultivos de cupuaçuzeiro. In: $1^{\circ}$ Seminário de Entomologia e Acarologia Agrícola na Amazônia (SEAMA). Resumos... Manaus: Sociedade Entomológica do Brasil. p. 184-204.

Silva, NM da, W de P Lemos, AMSR Pamplona, GM Lourido \& O Trevisan, 2016. Cupuaçu. pp. 137-157. In: Silva, NM da, R Adaime \& RA Zucchi (Eds.). Pragas agrícolas e florestais na Amazônia. Brasília: Embrapa.

Silva, RA da, CR de Jesus \& WR da Silva, 2007. Broquinha-docupuaçu: novo registro de praga no Estado do Amapá. Macapá: Embrapa Macapá (Comunicado Técnico, 123).

Silva Neto, P, PGG Matos, ACS Martins \& AP Silva, 2001. Sistema de produção de cacau para a Amazônia brasileira. Belém: CEPLAC.

Teixeira, CAD \& P van der Veld, 1997. As pequenas brocas do cupuaçu, Xyleborus sp. e Hypocryphalus sp. (Coleoptera: Scolytidae): danos e indicações de manejo em sistemas agroflorestais de Rondônia. Porto Velho: Embrapa Rondônia (Circular Técnica, 27).

The Plant List, 2013. A working list of all plant species. Available on: <http://www.theplantlist.org/1.1/browse/A/ Malvaceae/Theobroma/>[Access in: 17.ix. 2020].

Trevisan, O, JIL Moura, JHB Delabie \& ACB Mendes, 2011. Manejo integrado das pragas do cacaueiro do estado de Rondônia. Porto Velho: CEPLAC.

Trevisan, O, MAC de M Rodrigues, JIL Moura, W de P Lemos, JNM Costa \& NM da Silva, 2016. Cacau. pp. 73-93. In: Silva, NM da, R Adaime \& RA Zucchi (Eds.). Pragas agrícolas e florestais na Amazônia. Brasília: Embrapa.

Venturieri, GA \& JPL Aguiar, 1988. Composição do chocolate de amêndoas de cupuaçu (Theobroma grandiflorum). Acta Amazônica, 18: 3-8. DOI: https://doi.org/10.1590/180943921988182008

$\star \star * \star \star * * * * *$
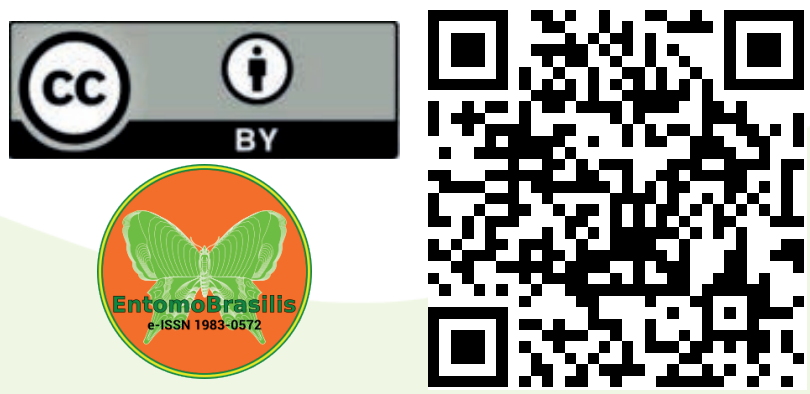